\title{
PENINGKATAN KETRAMPILAN MEMBACA INDAH GEGURITAN MELALUI TEKNIK "BASMI KORUPSII" SISWA KELAS VII-A DI SMPN 23 SURABAYA
}

\author{
NOVITA APRILIANTI \\ SMP Negeri 23 Surabaya, Jawa Timur \\ Novitaaprilianti1@gmail.com
}

\begin{abstract}
ABSTRAK
Penelitian ini bertujuan untuk mendekripsikan proses peningkatan ketrampilan membaca indah geguritan siswa kelas VII-A SMP Negeri 23 Surabaya semester genap tahun pelajaran 2020/2021 melalui teknik BASMI KORUPSII dan mendekripsikan peningkatan ketrampilan membaca indah geguritan siswa kelas VII-A SMP Negeri 23 Surabaya semester genap tahun pelajaran 2020/2021 melalui teknik BASMI KORUPSII. Penelitian ini merupakan penelitian tindakan kelas (PTK) yang menggunakan teknik analisis deskriptif kualitatif. Penelitian tindakan kelas (PTK) dilaksanakan untuk memperbaiki kondisi pembelajaran dan peningkatan kualitas pembelajaran. Penelitian ini dilaksanakan dalam dua siklus, yaitu proses tindakan pada siklus I dan siklus II. Sikus I bertujuan untuk mengetahui kemampuan siswa dalam membaca indah geguritan dengan teknik BASMI KORUPSII, sedangkan siklus II bertujuan untuk mengetahui peningkatan kemampuan siswa dalam membaca indah geguritan setelah dilakukan perbaikan dalam kegiatan pembelajaran siklus I. Ada empat tahap pokok pada penelitian ini yaitu perencanaan, pelaksanaan, pengamatan, dan refleksi. Teknik BASMI KORUPSII dipilih peneliti sebagai obat untuk mengatasi kesulitan siswa dalam pembelajaran ketrampilan emmbaca indah geguritan dengan tujuan untuk mempermudah siswa mengetahui trik bagaimana membaca indah geguritan. Pembelajaran dengan menggunakan teknik BASMI KORUPSII ini dapat meningkatkan ketrampilan siswa dalam membaca indah geguritan yang ditandai dengan peningkatan ketuntasan belajar siswa dalam setiap siklusnya, yaitu peningkatan dari siklus I yang memperoleh $45 \%$ mengalami peningkatan di siklus II menjadi $84 \%$.
\end{abstract}

Kata Kunci: Peningkatan, ketrampilan membaca indah, geguritan

\section{PENDAHULUAN}

Ada banyak cara mengapresiasi karya sastra. Karya sastra Jawa geguritan adalah salah satu karya sastra yang dipelajari siswa di kelas VII semester genap. Menurut Hutomo (1975: 26) di dalam kesustraan Jawa jaman kemerdekaan terdapat istilah guritan, guguritan, atau geguritan, yang berarti puisi bebas. Puisi bebas yang dimaksud adalah tidak terikat dengan peraturan-peraturan tertentu seperti halnya pada tembang macapat. Ada banyak sekali yang dapat digali ketika guru menyampaikan materi geguritan kepada siswa dan mengapresiasi geguritan adalah salah satunya. Mulai dari mengapresiasi struktur geguritan, memmaknainya, mengaitkan isi secara kontekstual, memprafrasekan, sampai dengan membaca indah geguritan.

Pada materi ketrampilan membaca indah geguritan, di masa pandemi ini peneliti mengajarkannya melalui video conference dengan platform Microsoft Teams. Tes unjuk kerja juga dilakukan langsung melalui video conference atau pengiriman melalui micosoft teams berupa video atau link yang diupload di media social. Kesulitan yang dihadapi siswa dalam pembelajaran membaca indah geguritan yang menggelitik peneliti melakukan penelitian di masa pandemi ini.

Siswa kesulitan membaca indah geguritan bukan berarti siswa tersebut tidak cakap dalam membaca. Siswa yang memiliki akademik bagus belum tentu memiliki kemampuan dalam hal ketrampilan membaca indah geguritan. Hal itu terjadi karena siswa belum mengetahui teknik yang tepat dalam membaca indah geguritan. Mereka menganggap hanya dengan cakap membaca, mereka juga mampu membaca indah geguritan. 
Hal tersebut merupakan penyebab siswa ketika melakukan tes unjuk kerja membaca indah geguritan, siswa mendapatkan hasil dibawah kriteria ketuntasan minimal. Teknik membaca indah geguritan yang disampaikan guru hanya disampaikan secara teori tanpa ada trik khusus membuat siswa semakin kesulitan untuk membaca indah geguritan sesuai dengan intonasi, artikulasi, ekspresi, gestur, dan jeda yang tepat. Sehingga terkesan hanya flat atau datar saja, padahal ketika membaca indah geguritan isi yang di dalam geguritan tersebut dapat tersampaikan kepada para pendengar "tidak hanya asal membaca cepat".

Permasalahan tersebut juga terjadi pada siswa kelas VII-A SMP Negeri 23 Surabaya pada semester genap tahun pelajaran 2020-2021. Para siswa mengalami kesulitan dalam membaca indah geguritan yang akhirnya berdampak pada hasil belajar dengan di bawah kriteria ketuntasan minimal. Karena kesulitan yang dihadapi siswa tersebut, akhirnya peneliti membuat teknik BASMI KORUPSII sebagai alat yang dipergunakan untuk mengurai benang kusut yang terjadi pada materi membaca indah geguritan. BASMI KORUPSII digunakan penulis untuk memudahkan siswa mengetahui trik dalam membaca indah geguritan supaya lebih mudah yang pada akhirnya dapat mentransfer isi yang terdapat dalam geguritan kepada para pendengar.

Dari penjelasan di atas dapat diambil rumusan masalah bahwa apakah teknik BASMI KORUPSII dapat meningkatkan ketrampilan membaca indah geguritan siswa kelas VII-A SMP Negeri 23 Surabaya pada semester genap tahun pelajaran 2020-2021. Menentukan istilah BASMI KORUPSII dalam teknik membaca indah geguritan adalah melalui proses menelaah dan mempelajari dari berbagai macam ahli yang dirangkum sehingga menjadi satu kesatuan yang tepat untuk mengatasi kesulitan belajar siswa dalam ketrampilan membaca indah geguritan.

Salah satunya adalah menurut Kamdhi (2003: 1) dalam bukunya menjelaskan bahwa membaca puisi adalah cara penyampaian isi perasaan, buah pikiran atau cerita sehingga penting cuntuk menghadirkan diri dengan cara bersuara yang memikat. Ucapan harus cukup keras, jelas, mengandung ekspresi perasaan, menggambarkan isi pikiran, serta mampu merangsang rasa keindahan. Tiga hal penting penting dalam membaca puisi yaitu: (1) teknik suara; (2) sikap jasmani; serta (3) cara penyampaian pesan. Dari pendapat dan beberapa sumber akhirnya peneliti membuat sebuah teknik yang merangkum menjadi istilah BASMI KORUPSII yaitu BAca, Serap Makna, perhatikan Intonasi, KOReksi artikUlasi, Pakai ekspresi, Sesuaikan gesture, Ingat jeda, simak contoh pembacaan puisI. Oleh peneliti menambahkan menyimak pembacaan puisi karena penting bagi siswa setelah mengetahui teknik kemudian menyimak bagaimana pembacaan puisi yang tepat. Sesuai dengan pendapat Trianto, (2014: 150) bahwa dalam suatu pembelajaran keterampilan atau pengetahuan tertentu, ada model yang bisa ditiru oleh siswanya. Dalam hal ini ketentuan model tidak hanya guru, akan tetapi bisa saja dari video atau teman sejawat.

Ada beberapa penelitian yang relevan berhubungan dengan penelitian tindakan kelas dengan materi membaca indah geguritan seperti yang telah peneliti lakukan yaitu pada penelitian Puspitosari (2016) dengan judul Ngundhakake Kawasisan Maca Geguritan Kanthi Metodhe Pemodhelan Tumrap Siswa Klas VII Smpn 1 Ngronggot Taun Ajaran 2015/2016, penelitian tersebut subjeknya adalah kelas VII, metode yang digunakan adalah pemodelan, teknik pengumpulan data yaitu teknik tes dan non tes. Penelitian tersebut sama-sama menggunakan materi membaca geguritan sebagai objek penelitian, akan tetapi yang membedakan adalah metode dan teknik yang digunakan sebagai obat. Penelitian tersebut menggunakan metode pemodelan sedangkan penelitian ini menggunakan teknik yang sudah dijadikan menarik oleh peneliti.

Selain itu, dalam penelitian Herminiati (2016) yang berjudul Modhel Pasinaon Langsung Kanthi Media Video Kanggo Ngundhakake Kawasisan Maca Endah Geguritan Siswa Kelas VII A Smpn 2 Kertosono Kabupaten Nganjuk memaparkan bahwa penelitian tersebut subjeknya adalah kelas VII, media yang digunakan untuk meningkatkan ketrampilan membaca indah geguritan adalah video. Teknik pengumpulan data yaitu teknik tes dan observasi. Penelitian tersebut sama-sama menggunakan materi membaca geguritan sebagai 
objek penelitian, serta kelas VII sebagai subjek penetian karena materi membaca geguritan memang ada di kelas VII. Akan tetapi yang membedakan adalah obat yang digunakan, penelitian tersebut menggunakan media video sebagai obat sedangkan penelitian ini menggunakan teknik membaca indah geguritan yang ada dalam BASMI KORUPSII.

\section{METODE PENELITIAN}

Penelitian ini merupakan penelitian tindakan kelas (PTK) yang menggunakan teknik analisis deskriptif kualitatif. Ada empat tahap pokok pada penelitian ini yaitu perencanaan, pelaksanaan, pengamatan, dan refleksi. Tempat penelitian adalah tempat yang digunakan dalam melakukan penelitian untuk memperoleh data yang diinginkan. Penelitian ini bertempat di kelas VII-A SMP Negeri 23 Surabaya, Jalan Baruk Barat Permai No. 1 Surabaya. Subjek dalam penelitian ini adalah siswa kelas VII-A tahun pelajaran 2020/2021 yang berjumlah 38 siswa, terdiri atas 22 siswa laki-laki dan 16 siswa perempuan. Data-data penelitian diperoleh melalui observasi pengelolaan teknik BASMI KORUPSII, observasi terhadap aktivitas siswa dan guru, dan tes. Penelitian ini terdapat dua siklus dengan masing-masing siklus ada tiga pertemuan karena mengingat waktu pembelajaran untuk kelas daring dikurangi dan tidak seperti ketika pembelajaran tatap muka.

\section{HASIL DAN PEMBAHASAN}

\section{a. Tahap Perencanaan}

Pada tahap ini peneliti mempersiapkan perangkat pembelajaran yang terdiri atas menyusun RPP (Rencana Pelaksanaan Pembelajaran), menentukan teknik membaca indah geguritan untuk kemudian dijadikan istilah yang membuat siswa mudah mengingat dan memahaminya, video membaca geguritan, dan alat-alat pengajaran yang mendukung. Selain itu juga dipersiapkan lembar observasi yaitu lembar observasi aktivitas guru dan siswa.

\section{b. Tahap Pelaksanaan}

Pelaksanaan kegiatan pembelajaran untuk siklus I dilaksanakan pada tanggal 4 Januari 2020 dan siklus II pada tanggal 25 Januari 2021 di Kelas VII-A dengan jumlah 38 siswa. Dalam hal ini, peneliti bertindak sebagai guru. Proses pembelajaran mengacu pada rencana pelajaran yang telah dipersiapkan.

Pelaksanaan tindakan kegiatan belajar mengajar pada siklus I dilakukan dengan langkah-langkah sebagai berikut:

1) Guru melalui video conference menjelaskan teknik membaca indah geguritan

2) Guru menayangkan power point.

3) Peserta didik membuat pertanyaan terkait materi membaca geguritan tersebut.

4) Guru membimbing peserta didik untuk mengumpulkan informasi yang sesuai untuk mendapatkan penjelasandan pemecahan masalah.

5) Guru meminta peserta didik menjelaskan makna geguritan yang telah dibuat sehingga pada pertemuan selanjutnya siswa sudah siap untuk membaca indah.

6) Guru memotivasi siswa untuk percaya diri membaca geguritan dan menyimak pembacaan geguritan yang telah dishare guru di teams atau menyimak referensi lainnya secara online.

7) Guru menayangkan video membaca geguritan.

8) Peserta didik membaca geguritan berulang kali, setelah itu memahami makna yang merupakan tahap dari teknik BASMI KORUPSII yang pertama supaya ketika membaca aspek artikulasi, intinasi, ekpresi, gestur, dan penempatan jeda bisa tepat sesuai denga isi geguritan.

9) Peserta didik membuat pertanyaan terkait video geguritan tersebut.

10) Guru meminta peserta didik melakukan unjuk kerja secara langsung dalam video conference. 
11) Siswa secara bergantian memberikan apresiasi lewat masukan langsung atau melalui emoticon yang tersedia di teams

12) Melakukan refleksi terhadap hasil pembacaan geguritan.

13) Membimbing peserta didik membuat simpulan kegiatan pembelajaran.

14) Guru memotivasi siswa untuk percaya diri membaca geguritan dan menyimak pembacaan geguritan yang telah dishare guru di teams atau menyimak referensi lainnya secara online.

Yang membedakan dengan siklus II yaitu pada 2 langkah perlakuan yang berbeda yaitu

Guru membaca indah geguritan melalui teknik BASMI KORUPSII dan Guru meminta peserta didik melakukan unjuk kerja melalui video yang dikirimkan sebelumnya melalui Teams.

\section{c. Tahap Observasi}

\section{Aktivitas Guru dan Siswa}

\section{(1) Siklus I}

Berdasarkan analisis data, keseluruhan hasil persentase aktivitas guru selama pembelajaran membaca indah geguritan siklus I sebesar 67,9\%. Terdapat lima jenis aktivitas yang dikatakan baik, dengan besar persentase 53,6\%. Lima jenis aktivitas tersebut meliputi jenis aktivitas guru dalam menyampaikan tujuan pembelajaran, menyampaikan materi, aktivitas guru dalam menghargai upaya hasil belajar siswa, dan aktivitas guru melaksananakan tahapan pembelajaran sesuai dengan Rencana Pelaksanaan Pembelajaran, dan aktivitas guru membantu siswa merefleksikan pembelajaran. Untuk dua aktivitas yaitu aktivitas guru memotivasi siswa dalam pembelajaran dan membimbing serta melatih siswa dalam pembelajaran menurut mendapatkan penilaian cukup baik dengan persentase $14,3 \%$.

Pada aktivitas siswa di siklus I dari enam aktivitas tidak ada yang mendapat penilaian sangat baik. Tiga aktivitas menunjukan cukup baik dan lainnya adalah baik. Jumlah persentase secara keseluruhan untuk aktivitas siswa adalah 60,6\%.

\section{(2) Siklus II}

Berdasarkan data aktivitas guru di siklus II rata-rata mendapat hasil sngat baik dan tidak ada yang mendapat cukup baik. Keseluruhan hasil persentase aktivitas guru selama pembelajarn membaca indah geguritan siklus II mengalami peningkatan yaitu $89,3 \%$.

Sejalan dengan aktivitas guru yang meningkat, pada aktivitas siswa Aktivitas siswa dalam memahami tujuan pembelajaran dan termotivasi dalam pembelajaran mengalami peningkatan yang signifikan karena semua dinilai cukup baik menjadi sangat baik. Hal itu dikarenakan perlakuan guru di siklus II juga sangat baik, akhirnya berimbas juga dengan peningkatan pada aktivitas siswa.

Aktivitas siswa mendapat bimbingan dalam pembelajaran, melakukan tes unjuk kerja sesuai teknik yang diberikan dalam pembelajaran, dan merefleksikan pembelajaran mendapat pengamatan dengan hasil baik. Keseluruhan hasil persentase aktivitas siswa pada pembelajaran menulis aksara murda siklus II sebesar 87,5\%. 
Peningkatan persentase aktivitas guru dan siswa dari siklus I dan siklus II dapat dilihat dari grafik berikut:

Gambar 1. Grafik aktivitas guru dan siswa pada siklus I dan II
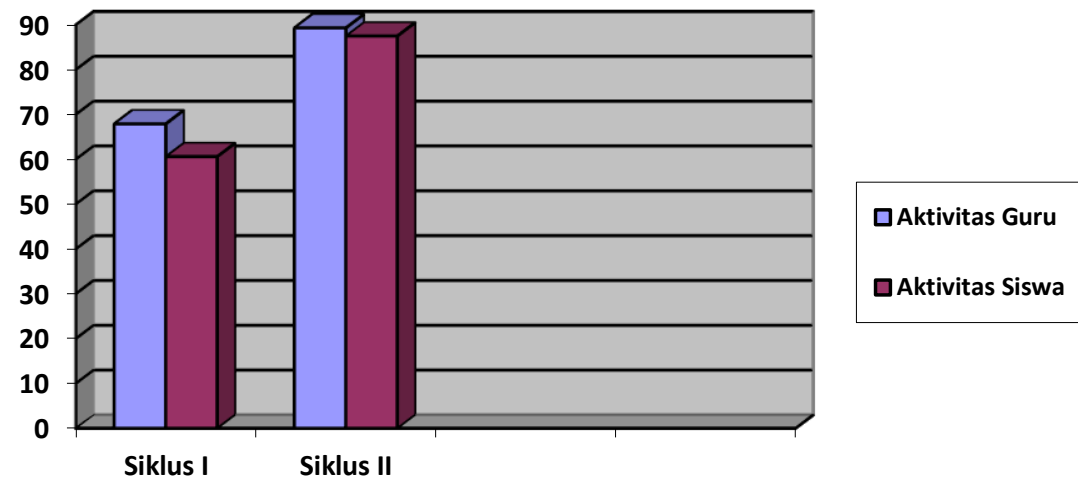

\section{Hasil Belajar Siswa}

\section{a. Siklus I}

Berdasarkan standar kriteria ketuntasan minimal yang ditetapkan oleh SMPN 23 Surabaya, yaitu pembelajaran dinyatakan tuntas apabila siswa dalam satu kelas memperoleh nilai sama atau di atas standar ketuntasan minimal mata pelajaran Bahasa Jawa dengan besaran 78, maka pada siklus I pembelajaran ketrampilan membaca indah geguritan hanya 17 dari 38 siswa yang tuntas. Selain itu, persentase ketuntasan siswa secara klasikal juga jauh standar $85 \%$, yaitu hanya $45 \%$.

b. Siklus II

Hasil belajar membaca indah geguritan pada siklus II mengalami peningkatan yaitu pada siklus I persentase ketuntasan siswa secara klasikal yang semula $45 \%$ di siklus II menjadi $84 \%$.

Dan dapat dijelaskan dalam grafik berikut:

\section{Grafik peningkatan persentase ketuntasan siswa}

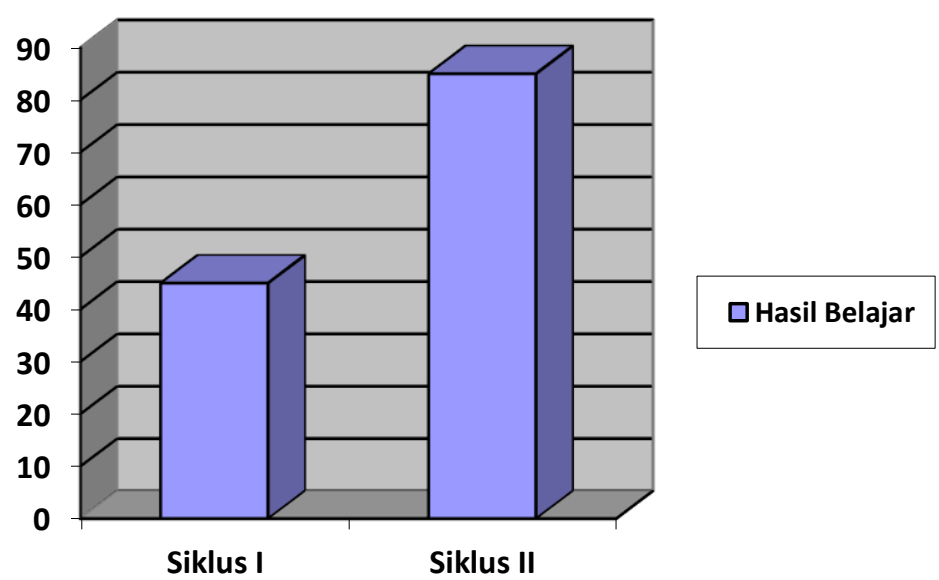

\section{d. Tahap refleksi}

1) Keberhasilan yang dicapai

Pada siklus I skor yang ditunjukkan pada penilaian intonasi dan artikulasi mencapai $92 \%$ dan $81 \%$. Pada siklus II hampir semua aktivitas guru dan siswa mengalami peningkatan. Guru dan siswa sama-sama menjalankan perannya selama proses pembelajaran. Peningkatan tersebut sejalan dengan peningkatan hasil belajar 
yang dicapai, hampir semua siswa memperoleh nilai di atas standar ketuntasan minimal yang ditetapkan.

2) Kekurangan yang terdapat pada pembelajaran

Pada siklus I hasil membaca indah geguritan dianalisis bahwa perolehan skor pada penilaian ekpresi, gestur, dan jeda masih kurang. Guru dalam aktivitas memberikan bimbingan kepada siswa dikatakan biasa saja. Pda siklus II Guru telah mengurangi intensitas pemberian bimbingan terhadap siswa karena telah terjadi peningkatan pemahaman akan teknik membaca indah dengan BASMI KORUPSII.

3) Rencana tindak lanjut

Berdasarkan kekurangan yang terdapat selama pembelajaran membaca indah geguritan pada siklus I berlangsung, beberapa hal akan diupayakan peningkatannya agar tejadi proses pembelajaran yang meningkat. Untuk pertemuan selanjutnya aktivitas guru dan siswa akan lebih ditingkatkan lagi.

Untuk meningkatkan hasil ketrampilan membaca indah geguritan, pada siklus berikutnya guru akan melakukan tes bukan secara langsung pada video conference tetapi melalui pengambilan video yang dikumpulkan sebelumnya kemudian akan ditampilkan pada kelas daring. Hal itu dilakukan supaya para siswa lebih bisa bergerak dengan leluasa ketika membaca indah geguritan. Perlakuan selanjutnya yang dilakukan pada siklus II adalah guru di setiap pertemuan akan mencontohkan membaca indah geguritan dengan menggunakan teknik BASMI KORUPSII. Dari hasil dan pembahasan di atas, aktivitas guru dan hasil belajar siswa dalam ketrampilan membaca indah geguritan dengan menggunakan teknik BASMI KORUPSII mengalami peningkatan di tiap siklusnya. Hasil tersebut diuraikan melalui deskripsi dan grafik seperti dalam pembahasan di atas.

Temuan tersebut sama halnya dengan penelitian yang dilakukan Indyah Herminiati dengan judul Modhel Pasinaon Langsung Kanthi Media Video Kanggo Ngundhakake Kawasisan Maca Endah Geguritan Siswa Kelas VII A Smpn 2 Kertosono Kabupaten Nganjuk ( Model Pembelajaran Langsung dengan Media Video untuk Meningkatkan Ketrampilan Membaca Indah Puisi Siswa kelas VII-A SMPN 2 Kertosono Kabupaten Nganjuk). Hasil penelitian menunjukkan adanya keberhasilan dan peningkatan aktivitas siswa dan guru, di siklus I ada 7 dari 12 kegiatan yang tuntas mengalami pengkatan menjadi 12 kegiatan yang tuntas di siklus II. Kegiatan guru juga terjadi peningkatan dari $72 \%$ di siklus I naik menjadi $78 \%$ di siklus II. Kenaikan tersebut juga mempengaruhi kenaikan hasil belajar siswa, yaitu dari $72 \%$ menjadi $78 \%$.

Penelitian tersebut memiliki persamaan dengan penelitian ini yaitu sama-sama menggunakan ketrampilan membaca indah geguritan sebagai objek penelitian, perbedaannya hanya pada teknik dan trik yang digunakan. Penelitian tidak semata-matanya hanya menggunakan media video, akan tetapi media video juga ada dalam bagian BASMI KORUPSII yaitu pada bagian simak contoh pembacaan puisi. Keberhasilan Yuni Puspitosari dalam penelitian memperkuat bahwa penelitian ini juga dapat meningkatkan ketrampilan membaca indah geguritan.

Keunggulan penelitian ini yaitu teknik BASMI KORUPSII digunakan siswa lebih mudah mengetahui trik dalam membaca indah geguritan yang pada akhirnya dapat mentransfer isi yang terdapat dalam geguritan kepada para pendengar. Beriringan dengan keunggulan, kelemahan dari teknik ini yaitu kurangnya kontrol guru secara langsung karena dilakukan 100\% daring. 


\section{PENUTUP}

Dari hasil siklus I dan siklus II serta berdasarkan seluruh pembahasan dan analisis yang telah dilakukan dapat disimpulkan sebagai berikut:

1) Dalam proses peningkatan ketrampilan membaca indah geguritan yaitu pada aktivitas guru dan siswa mengalami peningkatan selama dilakukan pembelajaran ketrampilan membaca indah geguritan.

2) Pembelajaran melalui teknik BASMI KORUPSII pada materi membaca indah geguritan dapat meningkatkan hasil belajar siswa yang ditandai dengan peningkatan ketrampilan membaca indah, yaitu siklus I 45\%, siklus II $84 \%$.

\section{DAFTAR PUSTAKA}

Arikunto, Suharsimi, dkk. 2015. Penelitian Tindakan Kelas. Jakarta: PT Bumi Akara

Hutomo, Suripan Sadi. 1975. Telaah Kesusastraan Jawa Modern. Surabaya: Pusat Pembinaan dan Pengembangan Bahasa

Herminiati, Indyah. 2016. Modhel Pasinaon Langsung Kanthi Media Video Kanggo Ngundhakake Kawasisan Maca Endah Geguritan Siswa Kelas VII A Smpn 2 Kertosono Kabupaten Nganjuk. Jurnal online Baradha, volume 1 no. 1

Kamdhi, J.S. 2003. Terampil Berekspresi. Jakarta: PT Gramedia Widiasarana Indonesia.

Prastiti, Sri. 2006. Paparan Kuliah Membaca I.Semarang: PBSJ

Puspitosari, Yuni. 2016. Modhel Pasinaon Langsung Kanthi Media Video Kanggo Ngundhakake Kawasisan Maca Endah Geguritan Siswa Kelas VII A Smpn 2 Kertosono Kabupaten Nganjuk. Jurnal online Baradha, volume 1 no. 1

Suyatmi. 1992. Membaca I. Surakarta: UNS Press.

Wardono. 1982. Titi Basa. Surabaya: Warga

Kelas pintar. 2020. Hal-hal yang Perlu Diperhatikan Dalam Membaca Puisi, (online), (https://www.kelaspintar.id/, diakses 28 Maret 2021)

Kosongin. 2020. Teknik, Penjedaan, dan Pengindraan dalam Puisi, (online), (https://www.kosongin.com/, diakses 28 Maret 2021) 